\title{
Implications of Multiple Land Ownership in Malaysia
}

\author{
Jasni Sulong and Mohd Marbawi Taha
}

\begin{abstract}
In Malaysia, it is apparently that the system of multiple land ownership is distinguished throughout the country. In term of implications, the exercise of existing legal system had resulted some intricacies pertaining to the land, especially in the context of social, economic and land development. Therefore, the purpose of this article is to analyze those connotations. It is hoped that we can contribute in improving the system of multiple-ownership in the country. The methodology that was used in this study is a library research as well as field study. Among library that was visited were universities library as well as the Library of National Institute of Land and Survey (INSTUN). Meanwhile in a field study, interviews was conducted with experts of the Land Office of States in Malaysia as well as practitioners who directly conducting cases of multi-ownership. The outcome of the study showed that the system of multi-ownership had resulted problems in some major aspects. Upon completion of the study we suggest that multi ownership systems should be reviewed by taking into account the interest of all parties on the land.
\end{abstract}

Index Terms - Land, multi ownership, joint land ownership, land law.

\section{INTRODUCTION}

Multiple land ownership was also known by coproprietorship under the Malaysian law. "Co-proprietorship" has been defined in Section 342 (1) of the National Land Code (NLC) as "the holding of alienated land by two or more persons or bodies in undivided portions" [1]. Generally, there are some differences between land that was held individually and land that was held jointly. Unlike land that was held by only a single proprietor, land of coproprietorship need more than one approval of consent in dealing with the land which often bring implications. In this case, the kind of possession can affect the land in various aspects such as in term of its development, economic value and social relationships. Hence, a study on the implications of multiple ownership is a quite significant to be discuss in this paper.

\section{IMPLICATIONS OF MULTIPLE LAND OWNERSHIP}

\section{A. Land Development}

According to The Department of Agriculture Malaysia, "idle land" is defined as an inland or paddy land with a minimum 0.4 hectare and above, either contiguous or

Manuscript received December 1, 2014; revised January 20, 2015.

Jasni Sulong is with the School of Humanities, University of Science Malaysia (USM), Malaysia (e-mail: jasni@usm.my)

Mohd Marbawi Taha is with the Academy of Contemporary Islamic Studies, MARA University of Technology (UiTM), Malaysia (e-mail: mohdmarbawi620@ppinang.uitm.edu.my). disperse ownership which is left unattended for three consecutive years [2].

Data from the Ministry of Agriculture shows that in year 2014, the area of idle land is about 119,273.39 hectares involving 69,734 lots in Peninsular Malaysia including Labuan. The information of idle land is very dynamic and always changes from time to time due to the increasing number of newly identified areas as well as of the decreasing in developing projects of lands [2].

The idle land and multiple ownership are two issues that are interrelated. Minister of Natural Resources and Environment, Datuk Seri Azmi Khalid had stressed many times that multiple ownership could restrained the land development [3]. Based on the research, multiple ownership is one of the main result that cause idle land. Therefore, the number of idle land could be decreased by lessening multiple land ownership throughout the country.

There are two identified factors that constrained the efficiency of land use under multiple ownership. The factors are co-owners behaviour and the existence of small portions in the multi ownership.

\section{1) Co-owners behaviour}

The attitude of co-owners in dealing with such land is very influential. They are legal owner of such land and every transaction must including them. Therefore if coowners are not on the same opinion in transactions, the process could be on difficulty. This situation will cause disputes and conflicts among co owners and eventually the land will be abandoned.

On this point, an awareness and willingness of owners on such activities on their shared land is very significant. Without those bases, co-owners will hardly to cooperate as well as refused to engage in any deeds. Overall, an agreement among them is very important no matter how small the portion they belong and on whatever dealings that are planned on that shared lands such as selling, leasing, altering land use, partitioning as well as subdivision.

Hence by ignorant of those faulty, co-owner will reluctant to do things as well as to pay for any expenses pertaining to activities of the land [4]. Some of them are even hardly fork out to pay for a premium cost. Moreover in the context of land in towns and cities, normally some of them are refusing to join in application for land use alteration in avoidance from being imposed with the higher tax by the government [3]. As a result, the land that has great potential to be developed becomes idle resulting from the selfish attitude of co owners.

In other situation, it is common that a dispute will be occurred pertaining whom to carry out responsibility in operating and managing the shared land [5]. This usually occurs in inheritance's land when some of heirs inclined to have their name being registered as one solely owner but in 
vain in developing the land collectively [6]-[7]. Eventually the land was left abandoned and does not give any benefit to heirs [7].

Obviously, different ideas among co-owner in developing the land would affect the progress of the land. The dissimilarity among co-owners in keeping the status-quo of the assets as well as to develop in gaining more economic value of the land will reflect solely to the land productivity. The uncollective decision among heirs will left the shared land to become an idle as well uncultivated [7].

There is a finding that shows that satisfaction must be built among co-owners in term of benefits and advantages. If they are not happy with some of profit-sharing or discussions, the feeling will spread to activities on the land in the future. In this case, the land will be abandoned and they will start doing another job instead of focusing on land development activities [5]. In total, misunderstanding and lack of co-operation among co-owners often being a detrimental factor on land activities that would affect the shared land.

\section{2) Limitation on land utilization}

Many lands in Malaysia are complicated to be developed because of its small size instead of joint-ownership, hence uneconomical for development. In order to evade, those lands should go under amalgamation process [8]. Only then, the development activities such as residential or commercial projects could be carried out.

Somehow land was in a normal size but as result of multiple ownership, the actual size of each ownership happen to be smaller and less significant. Reference [9] stressed that joint ownership is theoretically one form of land fragmentation which affects the efficiency of land use in the long run. For example, half acre of land that are divided equally among 8 beneficiaries will resulted each beneficiary only gets 2,722 square feet which is equivalent to 52 feet $\times 52$ feet [7]. With the size, not much can be done on such portion of the land which so-called small-scale land. In this regards, the increasing of joint ownership of the shared land will resulted to the decrease of the size of the land ownership.

As reported in Berita Harian on $5^{\text {th }}$ of August 2006, each of 90 co-owner on one land in Penang only entitled to possess about 1.8 square metre proportioned for every one of them [10]. Similar scenario took place in Kampong Bharu Kuala Lumpur after Utusan Malaysia on $8^{\text {th }}$ July 2006 reported that the smallest lot with an area of 809,345 square meters was owned by 141 co-owners. This will caused the smallest fraction on the land which is $7 / 424320$ or equivalent to 0.01335 square meter per ownership [10]. If one square meter is valued by the RM1000, therefore that portion is only worth RM13.35. Likewise in a land area of 0.003 acres owned by 10 people where the fraction of each owner become smaller and uneconomical [8].

The Minister of Natural Resources and Environment, Datuk Seri Azmi Khalid highlighted that the main problem of abandoned land is on the multiple ownerships. The predicament is on size of land that own by the proprietor. If someone own $1 / 210$ portion of such land, that means his portion is $1 / 210$ [3]. This scenario does not portray the number of ownership per se, but it also reveal the implication for developing the land. The fact is that when co-owners is increasing, the difficulty will also increasing. Thus, the number of ownership can influence the efficiency of land development [11]. The reality has been proved by a study that was conducted in Negeri Sembilan, where the owners are not interested in developing a small-scale land because the earning is not commensurate with the effort [12].

In addition, the existence of small-portion ownership will complicated the utilization of land [12]. If the portion of ownership is only $7 / 424320$ as happen in Kampong Bharu, the process for utilization will face more intricacy as one person will have to face abundant of co-owners. Eventually the land was left abandoned [7].

In other perspective, the existence of small-portion ownership could also contribute to the relationship deterioration among them. Actually, small portion of ownership will not make any difference in the benefit on the land as it was under value. However in the process of developing the land, the ownership become so influential in term of consent and approval. Without consideration on the size of one's ownership, a co-owner will have an authority to prevent any activity on that land by refusing in giving consent which may involve the authority of the court.

In order to avoid such difficulties, it is better for small portion owner to relinquish or transfer his right to other coowners [7]. Although the land carries his own sentimental value but the elucidation may fade away obscurity for the benefit of the land and heirs, where land could be developed and heirs will get their compensation.

\section{B. Local Development}

As was discussed, joint ownership not just contribute to the growing number of abandoned land, but also add an impediment for local development [10]. Refusal of one coowner for approval can cause developmental planning had to be amended or cancelled [13]. This has happened in some urban areas as well as in Kampong Bharu, Kuala Lumpur.

Kampong Bharu is situated in the heart of Kuala Lumpur City Center which was under Malay Reserve Land. It covers an area of 101.02 hectares and has a population of 45,000 people [14]. In number, total population density at Kampong Bharu is very high which is at 446 persons per hectare. Even though the location of Kampong Bharu is very strategic, but development of the land is lagging behind compared to the surrounding area. Infrastructures that exist in the neighbouring area are among the best in the world, especially on transportation facilities, communication networks, infrastructure facilities and many others. The question is, what is causing such situation?.

According to a paper presented at the briefing sessions for landlords in Kampong Bharu, the greatest problem facing in Kamping Bharu is multi-ownership of the land and the existence of small lot sizes [15]. Overall, Kampong Bharu consists of 884 lots and is owned by approximately 4300 owners. Based on records, $31 \%$ out of the total lots owned by more than 5 owners. The average land was owned by 8 to 30 owners [16]. In term of land area, it is found that $83 \%$ out of lots is less than 1000 square meters [15].

It is reported that the most crowded lot owners measuring 809.345 square metres and is owned by 141 people which is the smallest portion is a portion 7/424320 representing the 
area of 0.01335 square metres. Let say that one square meter is worth RM1000, so it is only worth RM13.35 [10].

The problem of multi-ownership in Kampong Bharu is no co-operation among owners. Their effort as well as feeling is not laying on the same step. Every single activity that was planned is futile when the consensus is hardly to be born [17]. For that reason, local development planning has been disrupted. Since two decades ago hitherto, although many programme was made for Kampung Baru by Kuala Lumpur City Hall (DBKL) however the planning is delayed [16].

Instead of difficulty in obtaining consent of all owners, another intricacy is in updating owners name on a paper. As most of them were scatterred around the country, where some of them just inherit from the deceased heirs. According to Nik Mohd Zain, Chairman of the Steering BIG Property Consultant, ${ }^{1}$ it was a difficult task to see all of the owners for approval [16]. If some of them is reluctant for consent, then the planning will be disrupted [13]. The only suggestion for solving the issue as the final step is the authority may use Section III (1) (b) of Land Aquisition Act 1960 which provides the right to acquire land even without the owner's consent [16].

\section{Land Revenue}

Multi-ownership may also slow down in generating a proper income from the land. Apart from depreciation of the land value, multi-ownership may obscured the process of obtaining loans from financial institutions as well as for leasing land to entrepreneurs.

\section{1) Depreciation of land value}

Depreciation of land value not just affected the land, but also has a negative consequence for co-owners. Most consumers don't want to purchase small portion of multiple ownership as it has low value [3]. Adding to that, the ownership also tend to root problems as it has to go for a tough process for selling and purchasing, mortgaging, leasing and etceteras [7]. As far as public concern about the matters, they will keep away from such possesion and add the number of abandoned land.

\section{2) Difficulty in obtaining financial support from financial institutions}

Normally, financial institutions are reluctant to offer loan for multi-ownership holder. According to [18], amongst the challenges of multi-ownership is the difficulty in obtaining loans from banks. In some cases, banks would go for declining of the application [18]. Even if the financial institutions accepted, consents of all co-owners are compulsorily required. The task is stand as a mutual agreement to serve as collateral. However the acceptance of all of co-owners is not easy as they will risk the loss of their right on the land. For example in the case of mortgage, if the owners who obtained loan from bank failed to make payment, the consequence of losing their land was involving all owners [3].

A substantial capital is needed to develop land, and hence failure in obtaining loan will affect the land development. A study shows that the growing number of abandoned land in Kuala Pilah is caused by the difficulty in obtaining loans.

\footnotetext{
${ }^{1}$ The Consultant that was appointed to draft Kampong Bharu development planning
}

There is a case where an application for bank loan was rejected as the land title bearing many nominees. As a result, that had hampered the interest for developing such land [19].

Based on the above discussions, it appears the multiple ownership can constrain the income of landowners. Although many Malay people own potential land for development, but they can not enjoy this advantage because of the constraints regarding joint ownership [3]. Therefore, form of ownership of a land will restrict the ability to gain capital for the owner, either for their living or business [3]. One of the main grounds of multi-ownership in the Muslim Malay community is through inheritance. In this case, the consensus among heirs in developing and managing the land is essential to ensure productivity and in the long run will benefit them.

\section{Social Relationship}

Joint ownership of a land should reflects on the close relationship among co-owners. However, review from academic writings were generally not reflect on that scenario. Insteads, multiple ownership had resulted various problem and hatred where disputes and disagreements usually occurred among them.

The breaking of social relationship among co-owners will resulted interruption of land development. For instance, the development's project in Duyong Island have been disrupted by a family problem. It cause an obstacle not just for the family land in particular but also involved the Duyong Island as a whole [20]. Likewise in case study that was conducted by [19] in Negeri Sembilan. A dispute between siblings pertaining cultivation activity on the land have resulted the land was left abandon [19].

The manner of co-owners among them are indispensable, especially when there are no physical borders of possession was made on the land. The dispute easily arise when the border among them is confused [10]. Although some has build fence or plant trees to subdivide among them [21], the practise will cause misunderstanding if the boundary was in uncertainty. According to Azharudin bin Abu Bakar, Assistant Director Estates Distribution Unit of Middle Kedah, among big problem of co-ownership is the practice of subdivision among them [10]. Nevertheless they want to enjoy their exclusive right of holding land, somehow the intention has harassed co-proprietors as well as violated their rights on the whole land.

The crisis among co-owners sometime prolong for generations. Based on Ariffin bin Sidek, ${ }^{2}$ conflict between two families over compensation of land acquisition by the state authority has spread to their children and grandchildren. This situation will added problems and intricacies regarding development of the land. Thus, by realizing the implication of multiple ownership on social aspect, serious awareness should be place among co-owners ${ }^{3}$. It must be stressed out that most of the disputes that occur in joint ownership involve family members. The good or the worst in cooperation among them will reflected their benefit of the land.

\footnotetext{
${ }^{2}$ Employed in Section of Land Acquisition, District and Land Office of Marang

3 Interview with Mat Ariffin bin Sidek in District and Land Office of Marang Terengganu, 2013.
} 


\section{CONCLUSION}

Empirically, there are evidents that multiple land ownership has resulted many negative implications especially in development aspect. If no action taken by authorities, such implications surely will affect the country in the long run. Therefore, there should be an effort by certain parties to reduce such implications. To scholars, it is time to contribute ideas and suggestions to enhance the existing system professionally. While on the other hand, the authority has to conduct a constant review so that no one will become a victim of an ineffective justice system.

\section{REFERENCES}

[1] Legal Research Board, The National Land Code 1965, Selangor: International Law Book Services, p. 325, 2011.

[2] The Department of Agriculture Malaysia. [Online]. Available: http://www.doa.gov.my/web/guest/maklumat-tanah-terbiar

[3] D. S. A. Khalid, Interview with the Minister of Natural Resources and Environment, Utusan Malaysia: Memudah Cara Pengurusan Tanah, 2008.

[4] M. S. Abdullah, "Isu Halangan Pembangunan Tanah di Pulau Duyong, Kuala Terenganu," Tanah Oh Tanah, Pustaka Firdausi, p. 114, 2011

[5] S. Bakar, "Implikasi sosial dan ekonomi dalam pembangunan tanah terbiar," presented at Workshop on Idle Land Development organized by the Ministry of Agriculture and Land and Regional Development, Serdang, Selangor, October 5-7, 1980

[6] H. M. Arabee, "Faktor-faktor yang menyebabkan ujudnya masalah tanah-tanah terbiar," presented at Workshop on Idle Land Development organized by the Ministry of Agriculture and Land and Regional Development, Serdang, Selangor, October 5-7, 1980.

[7] W. A. H. W. Harun, Mengurus Harta Pusaka, Selangor: PTS Professional, 2011, p. 171, 216, 225.

[8] R. Buyong, "Pembangunan kawasan simpanan melayu," presented at the Seminar on Meninggikan Nilai Tanah Rizab Melayu organized by University of Malaya, Kuala Lumpur, p. 39, 1979.

[9] C. Siwar, Kehendak dan Bentuk Reformasi Tanah di Malaysia, K.L.: Dewan Bahasa dan Pustaka, p. 83, 1976.

[10] B. Aziz, "Takharruj dalam pembahagian pusaka Islam: Kajian di Daerah Kota Setar," M.A thesis, Faculty of Geoinformation Science and Engineering, Universiti Teknologi Malaysia, p. 100, 2009.

[11] W. Senfteben, Background to Agricultural Land Policy in Malaysia. Wiesbaden: Schriften des Instituts fur Asienkunde, p. 170, 1978.

[12] M. Rindam, Tanah Terbiar: Masalah dan Penyelesaiannya, Kuala Lumpur: Dewan Bahasa dan Pustaka, p. 26, 1994.

[13] A. Said, "Halangan-halangan pembangunan tanah oleh faktor ekonomi, sosial dan politik," presented at the Seminar on Land Management organized by the Ministry of Agriculture and Land and Regional Development, Kuala Lumpur, p. 26, 1985.

[14] K. K. D. K. Baru. (2013). UM Students' Repository administration. [Online]. http://studentsrepo.um.edu.my/3253/6/BAB_3.pdf

Available:

[15] B. Othman, "Cadangan konsep dan kaedah perlaksanaan pembangunan Kampong Bharu, Kuala Lumpur," presented in Briefing to Landlords in Kampong Bharu, Kuala Lumpur organized by Ministry of the Federal Territories and Urban Wellbeing in conjunction with Kuala Lumpur City Hall. Kuala Lumpur, pp. 14-16, 2009.

[16] A S. Harian, Ramai Penama Sukar Usaha Bangunkan Kampong Bharu, 2008.
[17] I. Omar, Tanah Oh Tanah, Skudai: Pustaka Firdausi, p. 40, 2011.

[18] A. A. Manaf and I. Omar. (August 2011). Idle agriculture land resources management and development - An institutional causes: A case study in Malaysia. Interdisciplinary Journal of Research in Business [Online]. 1(8). pp. 21-27. Available: http://www.idjrb.com/articlepdf/idjrb8n3.pdf

[19] A. A. Manaf and I. Omar, Tanah Pertanian Terbiar: Analisis Ekonomi Intitusi, Pustaka Firdausi, p. 118, 2011.

[20] M. S. Abdullah. "Isu halangan pembangunan tanah di Pulau Duyong, Kuala Terenganu," in Tanah Oh Tanah, I. Omar, Ed., Skudai: Pustaka Firdausi, p. 114, 2011.

[21] U. A. Aziz, Land Disintegration ang Land Policy in Malaya, Universiti Malaya, p. 22

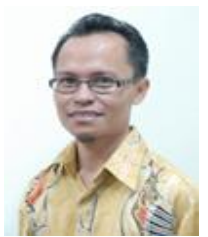

Jasni bin Sulong was born in Kuala Terengganu, Malaysia in 1974. His area of specialization is in the administration of Islamic law in Malaysia. Three of his degrees are from the Universiti Malaya, Kuala Lumpur. In 1998, he graduated his first degree with the first class honours in shariah. Three years later in 2001, he obtained his master in the same field of study, and pursued further of his doctorate lessons and achieved the scroll in 2006. He had an experience as a lecturer in many academic institution such as the Twintech University College and the Selangor Islamic College. After finishing his $\mathrm{PhD}$, he is currently serving as a senior lecturer at the School of Humanities, Universiti Sains Malaysia, Penang, Malaysia. He was also appointed as a coordinator for Islamic Studies at the Wawasan Open University, and a lecturer for master level at the Open University Malaysia. He had published articles relating to inheritance law and among of his latest contributions are the cases of special faraid: discussions and solutions (Nilai, Negeri Sembilan: USIM Press, 2013); the renewal law in the administration of Islamic inheritance (Penang, Malaysia: USM Press, 2011) and the legacy of hadeeth: between theory and the dinamic of thoughts (Penang, Malaysia: USMPress, 2008). In the State of Penang, Dr. Sulong was selected as a member in the Penang Shariah technical committee which was set up under the Department of Islamic Religious. His research interest are more about Islamic inheritance law and its administration as were portrayed through his writings.

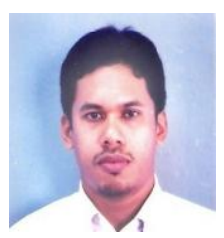

Mohd Marbawi bin Taha was born in Kuala Terengganu, Malaysia in 1974. His area of specialization is in the Islamic and Arabic Studies. He graduated from the University of $\mathrm{Al}$ Azhar, Egypt in 1998 with the degree of Islamic and Arabic studies. In 2007, he obtained the M.A of Shariah from University of Malaya, Malaysia in the field of the fiqh and usul. He had an experience in Malayan civil service in the State Secretariat of Terengganu before turning to be a lecturer in Arabic language at International Islamic University of Malaysia for five years. Now, he is currently serving as a university lecturer in MARA University of Technology in Penang, Malaysia and at the same time pursuing his $\mathrm{PhD}$ at the School of Humanities Universiti Sains Malaysia, Penang, Malaysia. For his doctoral thesis, Marbawi is doing his research on "Multiple Land Ownership in Malaysia: An Analysis From Islamic Perspective." He had published articles relating to land issues. 